TAPROBANICA, ISSN 1800-427X. April, 2013. Vol. 05, No. 01: 19-31. (C) Taprobanica Private Limited, 146, Kendalanda, Homagama, Sri Lanka. www.taprobanica.org

\title{
REVALIDATION OF Lycodon hypsirhinoides (THEOBALD, 1868) FROM ANDAMAN ISLANDS (SQUAMATA: SERPENTES: COLUBRIDAE)
}

\section{Gernot Vogel ${ }^{1}$ and S. Harikrishnan ${ }^{2}$}

\author{
${ }^{1}$ Society for Southeast Asian Herpetology, Im Sand 3, D-69115 Heidelberg, Germany \\ E-mail: Gernot.Vogel@t-online.de \\ ${ }^{2}$ Wildlife Institute of India, P. O. Box \# 18, Dehra Dun, Uttarakhand, 248001, India.
}

\begin{abstract}
The Andaman population of the genus Lycodon is compared to Lycodon capucinus Boie, 1827 and Lycodon aulicus (Linnaeus, 1758) occurring on the eastern and western parts of the range of this species complex. The population was found to be distinct and the species name Lycodon hypsirhinoides (Theobald, 1868) is revalidated for this population. It differs from both species in the size, proportions and colouration of adults and juveniles.
\end{abstract}

Key words: Lycodon aulicus, Lycodon capucinus, Andaman endemics, invasive species, taxonomy

\section{Introduction}

The genus Lycodon Boie, 1826 currently comprises 36 species (Uetz, 2012). This genus is characterized by the following combination of characters: head depressed dorsoventrally, barely set off from body; a relatively small eye with a vertically elliptic pupil; large nostril; an upper maxillary bone both strongly arched and bent inwards anteriorly; anterior maxillary teeth curved, with a gap between the very large anterior teeth and the subsequent ones; dorsal scales smooth or feebly keeled in 17,19 , or 21 rows at mid-body, and the ventrals rounded (Malkmus et al., 2002). Species of this genus are small to medium sized, crepuscular to nocturnal ground dwellers with a good ability to climb. They feed mainly on lizards, frogs, and snakes. Juveniles usually possess more intense colours and more contrasting patterns. All species are oviparous (de Lang \& Vogel, 2005). Some are anthropophilous species, living close to human settlings, making dispersal by humans likely.

New species in this genus are continuously described (Ota \& Ross, 1994; Mukherjee \& Bhupathy, 2007; Vogel et al., 2009; Vogel \& David, 2010; Vogel \& Luo, 2011; Zhang et al., 2011). Like many other larger snake genera, Lycodon is badly in need of a review. There have been no phylogenetic investigations, so the evolutionary relationship of species in the genus remains unresolved. At least one species 
of the genus, Lycodon capucinus Boie, 1827, is known to be easily introduced to non-native areas and is increasing its range (Smith, 1988; Fritts, 1993). Considering the issues surrounding invasive species such as Lycodon capucinus (Cogger, 2006), it is important to know the biogeographic patterns of members of the Lycodon aulicus-capucinus complex. The constant delay of these tasks will lead to problems in reconstruction of the original distribution area and might lead to unnoticed extinction of similar species, especially of the same genus. The introduction of an invasive species might be disguised. The disastrous results of the introduction of invasive snake species are well known (Rodda \& Fritts, 1992; Rodda et al., 1999, Cogger, 2006).

The long and confusing history of the genus name is discussed by Adler \& Zhao (1995). The history of the species names Lycodon aulicus and L. capucinus has a similar complex past. It is beyond the scope of this paper to discuss the taxonomic history of these names in detail. Since Taylor (1965), both taxa are usually treated as full species (but see Lanza 1999). In 2007, another species of this group was described from South India as Lycodon flavicollis Mukherjee \& Bhupathy, 2007.

In 1868, Theobald described Tytleria hypsirhinoides based on a single specimen collected by R. C. Tytler from the 'Andamans, in the Bay of Bengal'. He created the new genus by monotypy and compared this genus only with the genus Hypsirhina (now a synonym of Enhydris). The species was synonymized with Lycodon aulicus (including L. capucinus), by Theobald in 1876 . Since then, it was treated as a subjective synonym of Lycodon aulicus or later Lycodon capucinus by others (Boulenger, 1893; Smith 1943) without being discussed. Das et al. (1998) listed the holotype in the collection of ZSI (ZSI 8145) (Figs. 1, 2). We show that the population from Andaman Islands warrant species status based on the biological species concept, i.e., a diagnosable, reproductively isolated population that does not naturally interbreed with other populations. The insularity of this population means it has an evolutionary history distinct from other Lycodon populations elsewhere, and we resurrect its species status as Lycodon hypsirhinoides (Theobald, 1868).

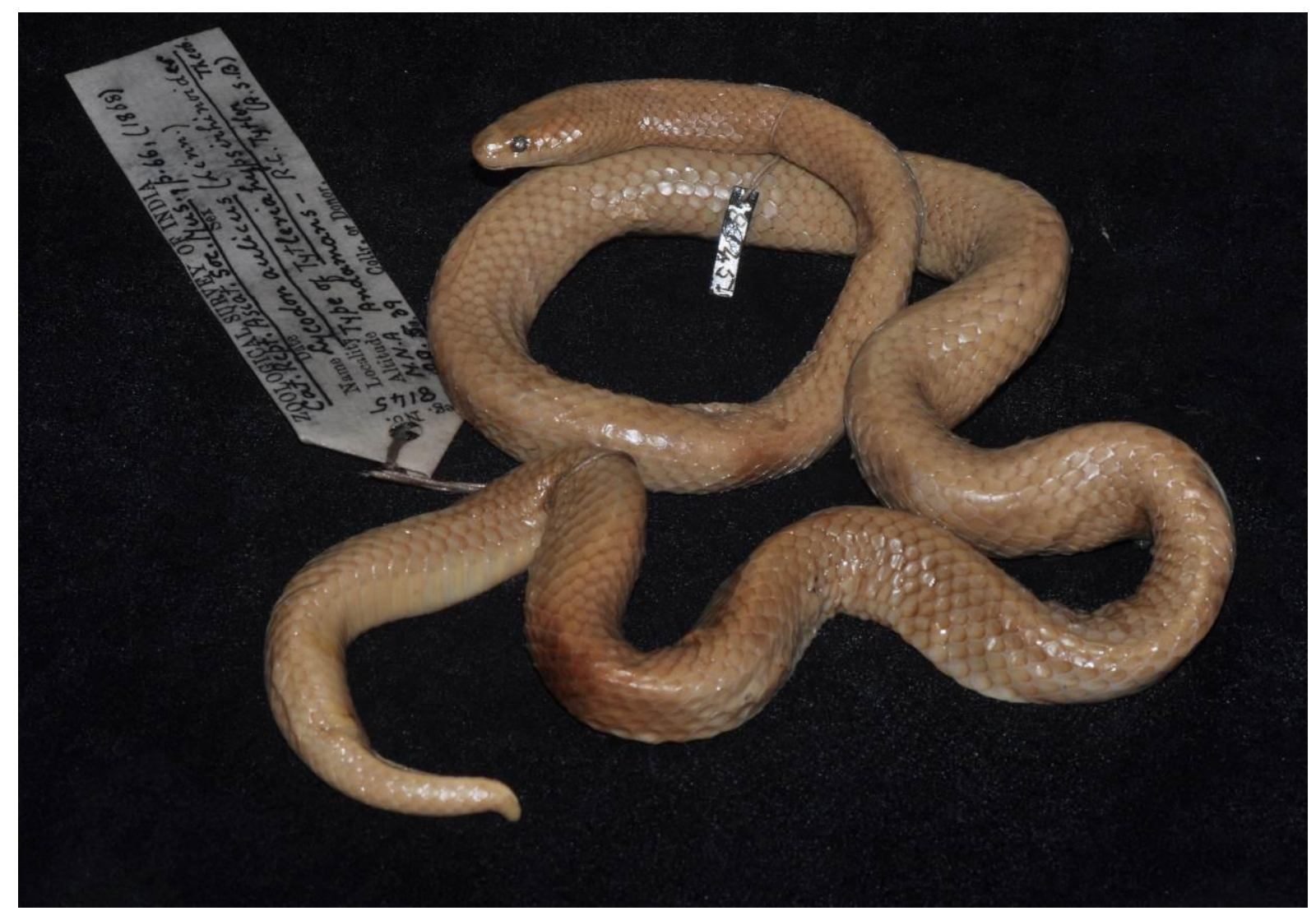

Figure 1: Holotype (ZSI 8145) of Tytleria hypsirhinoides Theobald, 1868 


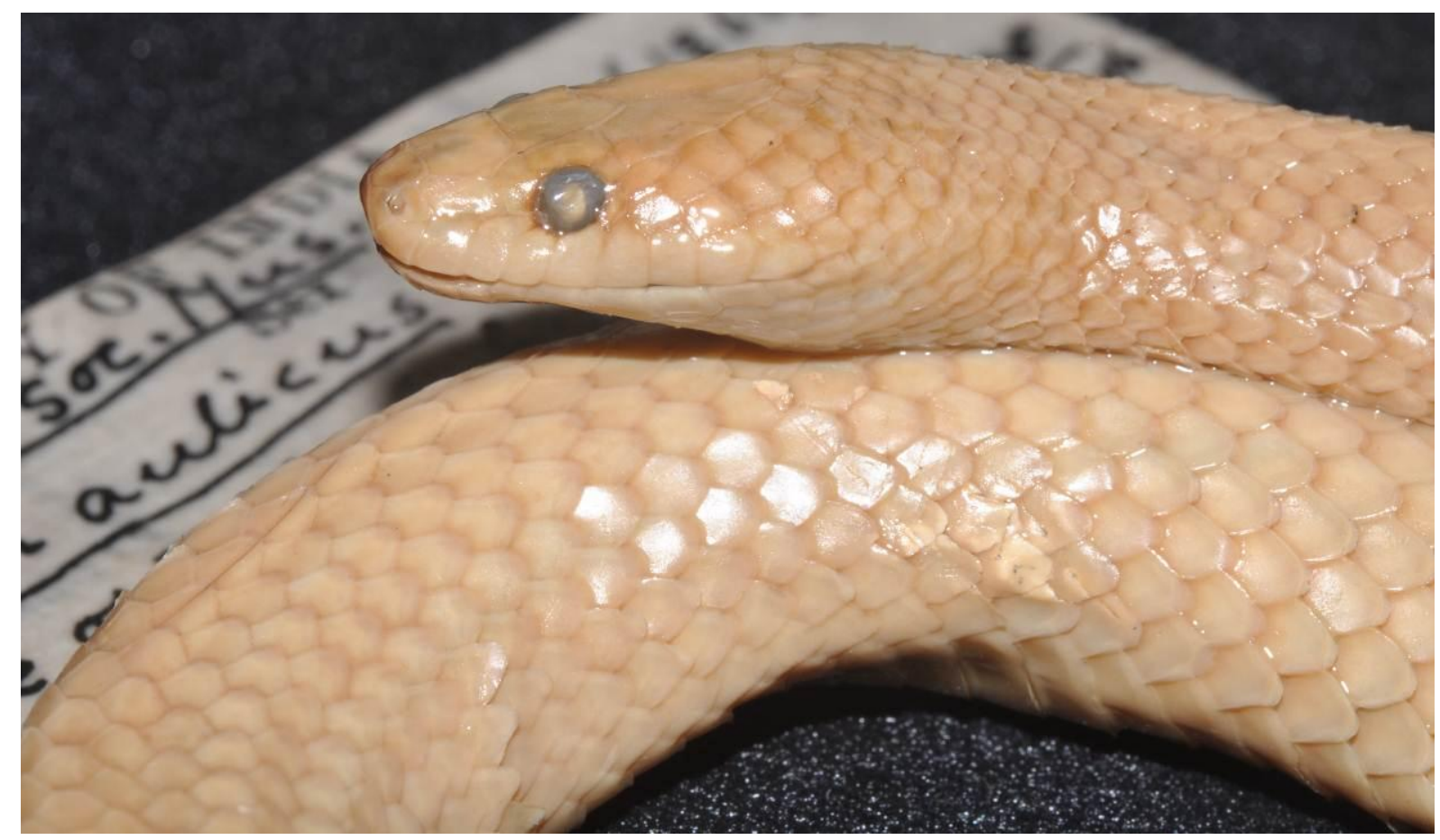

Figure 2: Holotype (ZSI 8145) of Tytleria hypsirhinoides Theobald, 1868; head and anterior body

\section{Material \& Methods}

We compared 13 preserved and 26 live and uncollected specimens (for colour in life) of $L$. hypsirhinoides from different islands of the Andamans with 15 preserved and about 10 live specimens of Lycodon capucinus and 16 preserved and a larger number of live specimens of Lycodon aulicus. The preserved specimens were examined for external morphological characters and dentition (Appendix I). Twenty nine morphological and colouration characters were recorded for each specimen (Appendix 2). Not all of these characters were useful to distinguish between species in this study, but all of them were compared because they may be useful for further taxonomic actions.

Measurements, except body and tail lengths, were taken with a slide-caliper to the nearest $0.1 \mathrm{~mm}$; all body measurements were made to the nearest millimeter. The number of ventral scales was counted according to Dowling (1951). Half ventrals were counted as one. The first scale under the tail meeting its opposite was regarded as the first subcaudal, the terminal scute was not included in the number of subcaudals. The dorsal scale rows were counted at one head length behind head, at midbody (i.e., at the level of the ventral plate corresponding to a half of the total number of ventrals), and at one head length before vent.
We considered sublabials being those shields that were completely below a supralabial. Values for paired head characters are given in left / right order. The sex was determined by dissection of the ventral tail base when possible or by everting the hemipenes in male specimens.

Museum abbreviations: BMNH: The Natural History Museum, London, UK; CAS: California Academy of Sciences, San Francisco, USA; NMW: Naturhistorisches Museum Wien, Vienna, Austria; SMF: NaturMuseum und Forschungs-Institut Senckenberg, Frankfurt-am-Main, Germany; ZFMK: Zoologisches Forschungsmuseum Alexander Koenig, Bonn, Germany; ZMB: Zoologisches Museum für Naturkunde der HumboldtUniversität zu Berlin, Berlin, Germany; ZSI: Zoological Survey of India, Kolkata, India; HC: Wildlife Institute of India collection to be deposited at ZSI. Other abbreviations: SVL: Snout-vent length (mm); TaL: Tail length (mm); TL: Total length (mm); Rel TL: Relative tail length $\mathrm{TaL} / \mathrm{TL}$

\section{Results}

Theobald's original description of the type is brief (Theobald, 1868), and we quote below the description of the genus and species verbatim. Page 66: 


\section{"TYTLERIA, Theobald.}

Aspect of Hipsirhina. Scales, smooth, in seventeen rows. Nostril lateral, almost dividing a smallish oblong nasal: frontals two pair: three upper labials enter the orbit. Loreal elongate: anal and subcaudals bifid: eye small; pupil vertical.

T. hypsirhinoides, Theobald.

Habit moderate, aspect of the Enhydrinae. Head shield normal. Anterior frontals slightly pentagonal, half as large as posterior. Nasal a trifle less than loreal. Ante-ocular one, reaching to the vertical. Postoculars two, small. Vertical straight in front, sides rapidly converging behind. Superciliaries moderate, broad behind. Occipitals moderate. Upper labials nine, 3rd, 4th and 6th enter the orbit. Two pairs of chin shields touching one another. Sixth lower labial largest, touches the middle of second chin shield. Color uniform reddish brown above. Belly yellowish white, length 21.00, tail injured 1.00 $=22.00$ inches.

a. type specimen. Andamans. Lt.-Col. Tytler."

Diagnosis: A relatively large species of Lycodon (max. total length $717 \mathrm{~mm}$ ) with stout body; juveniles with a speckled brown/white pattern on body and a dark brown head with white collar; adults uniform dark brown; collar band absent or very faint in younger specimens; body scales in 17:17:15, ventrals $188-210$, divided anal, subcaudals 61-75.

\section{Redescription of the holotype of Tytleria hypsirhinoides (ZSI 8145):}

Holotype: ZSI 8145: unknown sex; Andamans (in the Bay of Bengal, India); Coll. R. C. Tytler; Date. Unknown (The holoype is a relatively large individual of unknown sex. Sex determination was not possible since we could not dissect the unique specimen but due to the number of ventrals we assume that it is a female. The specimen was soft to touch and very flexible).

Body stout; snout-vent length $525 \mathrm{~mm}$ : most of the tail missing; total length $550 \mathrm{~mm}$; head depressed, dorso-ventrally flattened, widest at the temporal region; 9/9 supralabials, 3rd to 5th in contact with the eye; rostral broader than high; anterior and posterior nasals of similar size, nostril in the division of the two; single elongated loreal; loreal in broad contact with internasal and second and third supralabials; $1 / 1$ preocular, in contact with the frontal; $2 / 2$ post-oculars; temporals $2+3$, subequal in size; internasals about half as long as prefrontals; prefrontals wider than internasals; frontal large, as long as the combined length of internasals and prefrontals; supraoculars about half as wide as frontal; parietals about 1.5 times as long as frontal; mental triangular, narrower than rostral; $10 / 10$ infralabials, first pair in contact with each other, sixth largest; anterior genials a little longer than posterior; scales in 17:17:15 rows; 210 ventrals, with a notch on either side; divided anal; 13+ subcauduals (tail incomplete).

Colour in alcohol: The entire specimen is pale buff coloured, a little lighter on the ventrals.

Natural history: Lycodon hypsirhinoides is a common snake, occurring in many of the islands in the Andaman Islands. Though it is often found close to human habitation, it is also common in evergreen and semi-evergreen forests. Individuals were found in leaf-litter, under tree bark, tree holes, and inside rotting $\operatorname{logs}$ and lianas. All active individuals were found at night. It is a shy snake that rarely bites when captured.

Despite the fact that the main differences between the Andaman population and the other species are the total length and the colouration of juveniles and adults, there can be no doubt that this population is specifically different from $L$. capucinus, $L$. aulicus and $L$. flavicollis. The differences from $L$. aulicus, and $L$. flavicollis are obvious and need no further explanation (see the discussion).

At the moment, L. hypsirhinoides is regarded as an objective synonym of $L$. capucinus. $L$. capucinus is a species with a wide distribution in Asia. It is known from Australia (Cook Islands), Myanmar, Cambodia, Thailand, Vietnam, Singapore, Laos, SE China, India , Indonesia (Sumatra, Java, Bali, Borneo, Sumbawa, Sumba, Komodo, Flores, Lomblen, Alor, Sawu, Roti, Timor, Wetar, Babar Islands, Kalao, Salajar, Buton, Sulawesi, Lombok, 
Moyo, Adonara, Pantar, Kisar, Semau), West Malaysia, Maldives, Mascarenes, and Philippine Islands (David \& Vogel, 1996; How et al., 1996; Uetz, 2012). For comparison, we used specimens of populations from localities being distributed all over the species range as: Java, Borneo, Flores, Lombok, Timor, Thailand, Vietnam and Philippines (Samar). These localities were chosen to get a wide range of variation and to determine whether populations differ from each other in a way the Andaman population differs from them. It was quite astonishing to see that there was hardly any variation in the colouration of the specimens of L. capucinus. This was already noted for this species by Leviton on the Philippines (1965), where it is widely distributed and by Mertens (1930) and How et al. (1996) for the Lesser Sunda Islands. How et al. (1996) especially noted that there is no variation in colour or pattern by the studied specimens.

\section{Discussion}

Lycodon hypsirhinoides differs from $L$. aulicus in colouration (dark-brown against middle/reddish brown), pattern (uniform against banded anteriorly), the missing light collar (present in L. aulicus) and a larger body size in males. Further, colouration and pattern of juveniles is different. Juvenile $L$. aulicus resemble adults in colour and pattern, and there is no ontogenic shift in colouration. Juvenile $L$. hypsirhinoides have a speckled dark brown and white appearance (Fig. $3 \& 4$ ), which fades and becomes uniform dark brown or nearly black in adults (Fig. 5 \& 6).

Table 1: Comparison of most informative morphological characters of three members of the Lycodon aulicuscapucinus group (Abbreviations, see Material and Methods), TL in mm.

\begin{tabular}{|c|c|c|c|c|}
\hline \multicolumn{2}{|c|}{ Character -2 Taxon } & $\begin{array}{l}\text { Lycodon } \\
\text { hypsirhinoides } \\
(n=13)\end{array}$ & $\begin{array}{l}\text { Lycodon } \\
\text { capucinus } \\
(\boldsymbol{n}=13)\end{array}$ & $\begin{array}{l}\text { Lycodon } \\
\text { aulicus } \\
(n=6)\end{array}$ \\
\hline \multirow{2}{*}{ VEN } & $\sigma^{\pi}$ & $188-202, \bar{x}=195$ & $183-194, \bar{x}=189$ & $200-205, \bar{x}=203$ \\
\hline & q & $199-210, \bar{x}=205$ & $193-205, \bar{x}=199.7$ & $203-211, \bar{x}=206.8$ \\
\hline \multirow{2}{*}{$\mathrm{SC}$} & 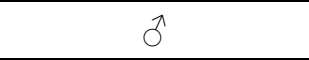 & $68-75, \bar{x}=72$ & $66-72, \bar{x}=69.5$ & $69-78, \bar{x}=73.5$ \\
\hline & q & $61-68, \bar{x}=65.5$ & $64-69, \bar{x}=66.4$ & $59-70, \bar{x}=66.3$ \\
\hline \multirow{2}{*}{$\begin{array}{c}\mathrm{TaL} / \mathrm{TL} \\
{[\overline{\mathrm{x}}]}\end{array}$} & $\theta^{\pi}$ & 0.202 & 0.193 & 0.187 \\
\hline & q & 0.179 & 0.180 & 0.171 \\
\hline \multirow{3}{*}{ Juveniles } & Light collar & Present & Present & Present \\
\hline & Body pattern & Reticulated & Reticulated & Banded \\
\hline & Body color & $\begin{array}{l}\text { Brown-white } \\
\text { speckled }\end{array}$ & $\begin{array}{l}\text { Middle brown } \\
\text { /purplish-brown }\end{array}$ & Brown \\
\hline \multirow{3}{*}{ Adults } & Light collar & Absent & Present & Present \\
\hline & Body pattern & Absent & Reticulated & Banded \\
\hline & Body color & Dark brown/black & $\begin{array}{l}\text { Middle brown } \\
\text { /purplish-brown }\end{array}$ & Brown \\
\hline \multirow{2}{*}{$\begin{array}{l}\text { Adults / } \\
\text { juveniles }\end{array}$} & $\begin{array}{l}\text { Upper labials dark } \\
\text { centres }\end{array}$ & No & Yes & Yes/no \\
\hline & $\begin{array}{l}\text { Onto-genetic colour } \\
\text { shift }\end{array}$ & Yes & No & No \\
\hline \multirow{2}{*}{ Max. TL } & $\hat{0}$ & 717 & 560 & 463 \\
\hline & q & 563 & 599 & 594 \\
\hline Max.TL & $9 /{ }^{\pi}$ & 0.785 & 1.069 & 1.28 \\
\hline
\end{tabular}




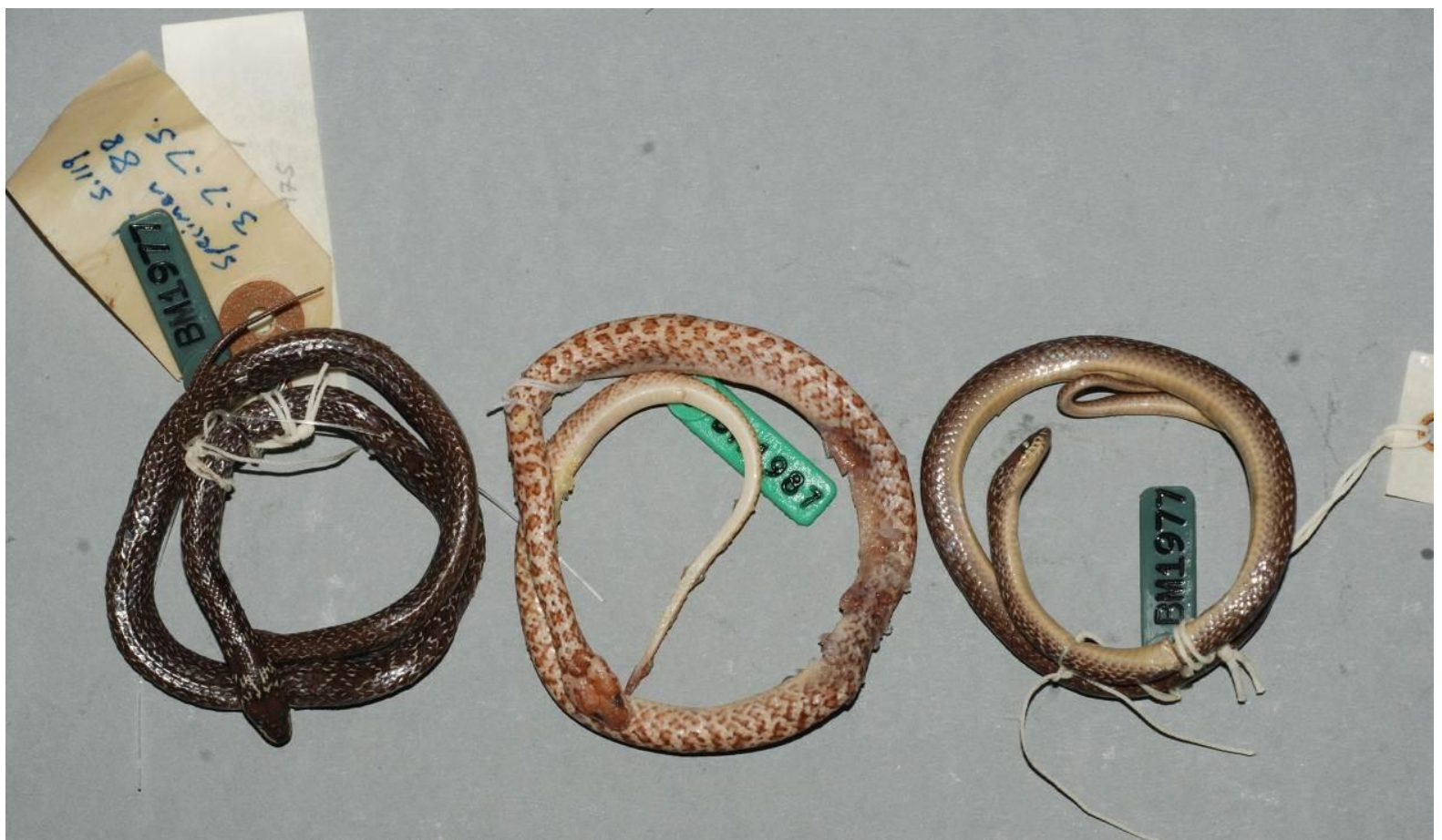

Figure 3: Comparison of the juvenile colouration of L. hypsirhinoides (BMNH 1987.889 middle) with two $L$. capucinus (both from Phuket Island, Thailand). Specimens with a similar length and a similar preserving time.

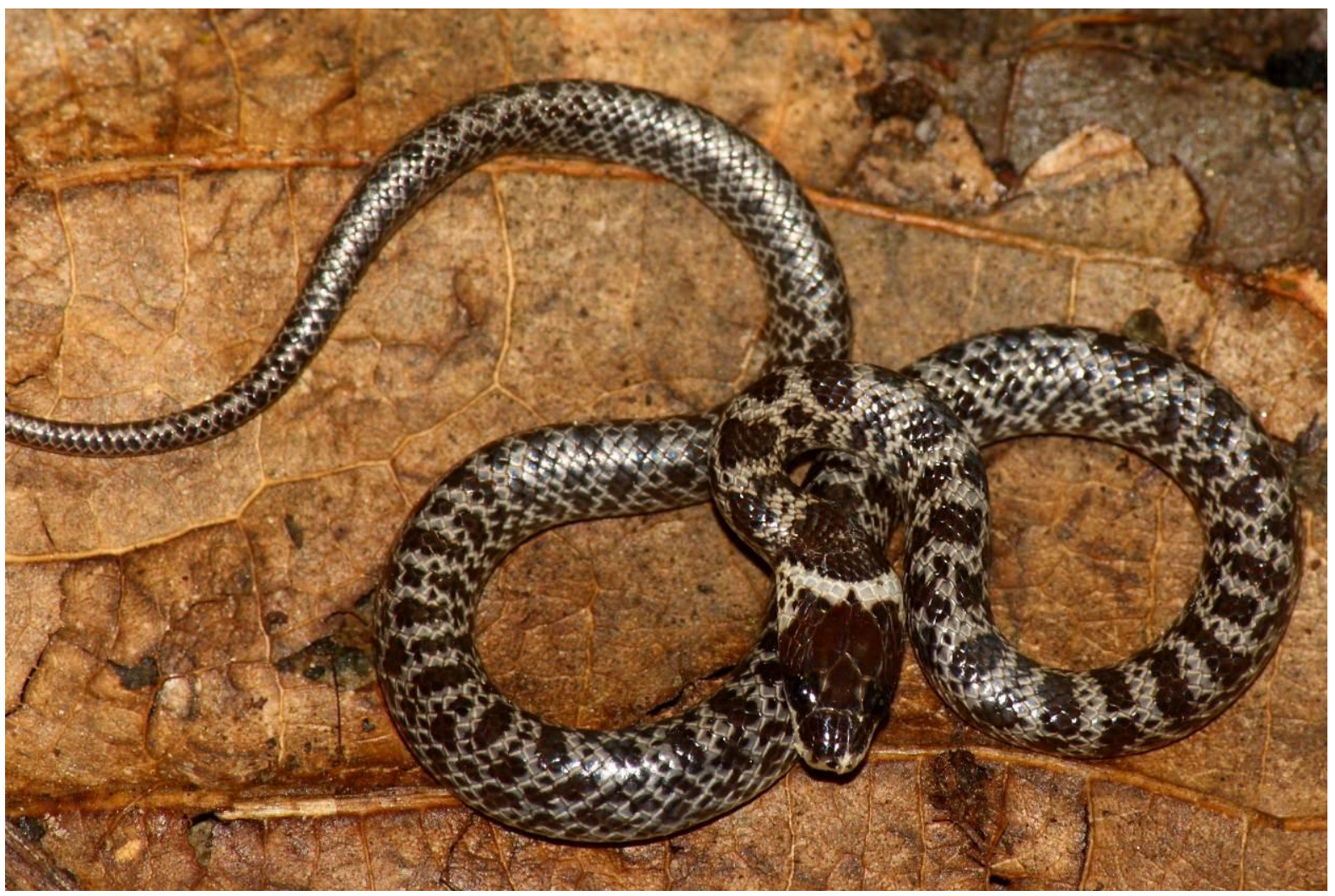

Figure 4: Juvenile of L. hypsirhinoides (Theobald, 1868) from South Andaman Island. 


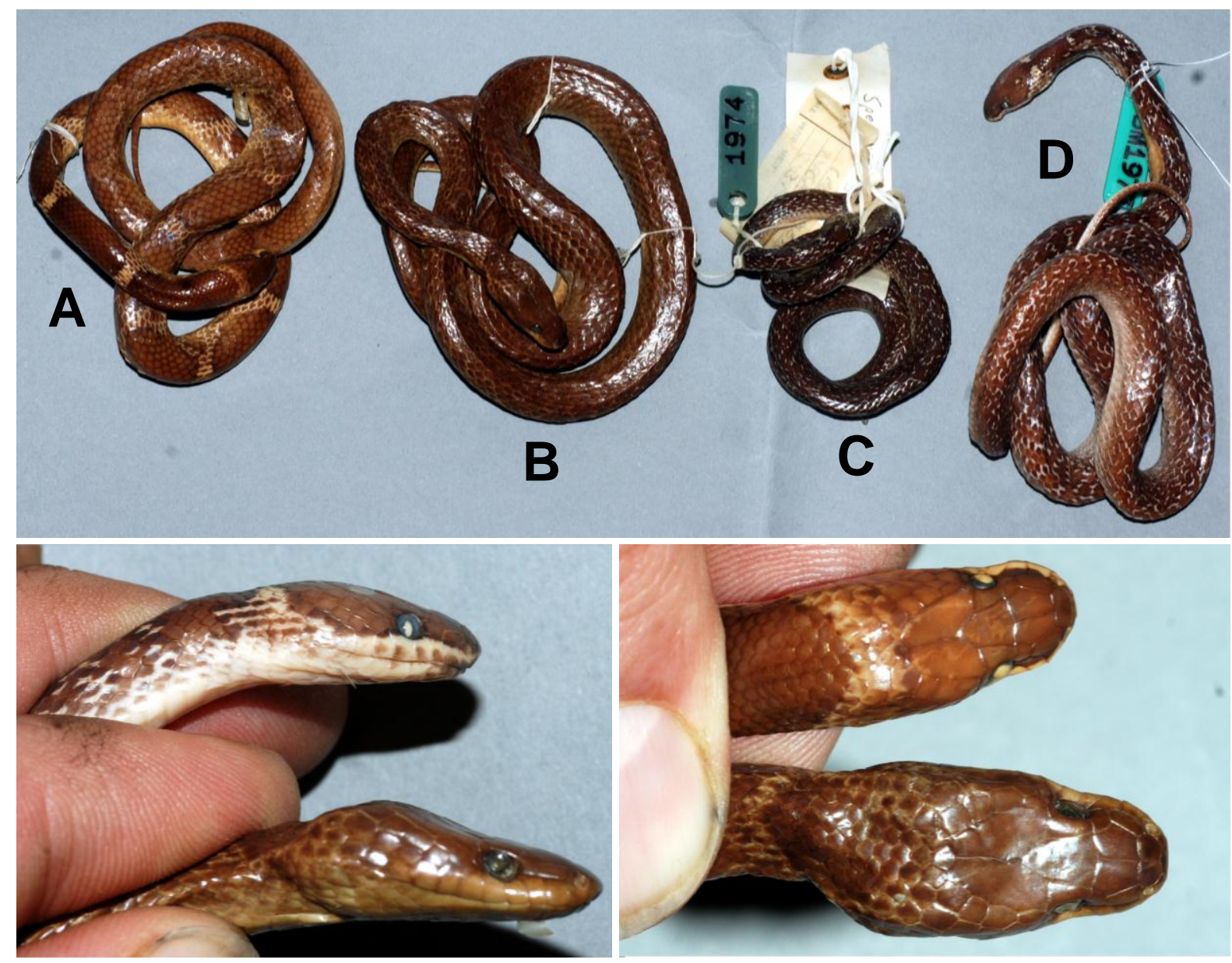

Figure 5: Adults of Lycodon aulicus-capucinus complex. (Top) A, L. aulicus from Banglore, India; B, L. hypsirhinoides from Andaman Islands; C, L. capucinus from Phuket, Thailand; D, L. capucinus from Java. (Bottom) Comparison of the head of L. capucinus (upper) and L. hypsirhinoides (lower). Notice the distinct widening of the occipital region and the lack of dark spots in the middle of the suplabials in L. hypsirhinoides. Both specimens are of similar SVL.

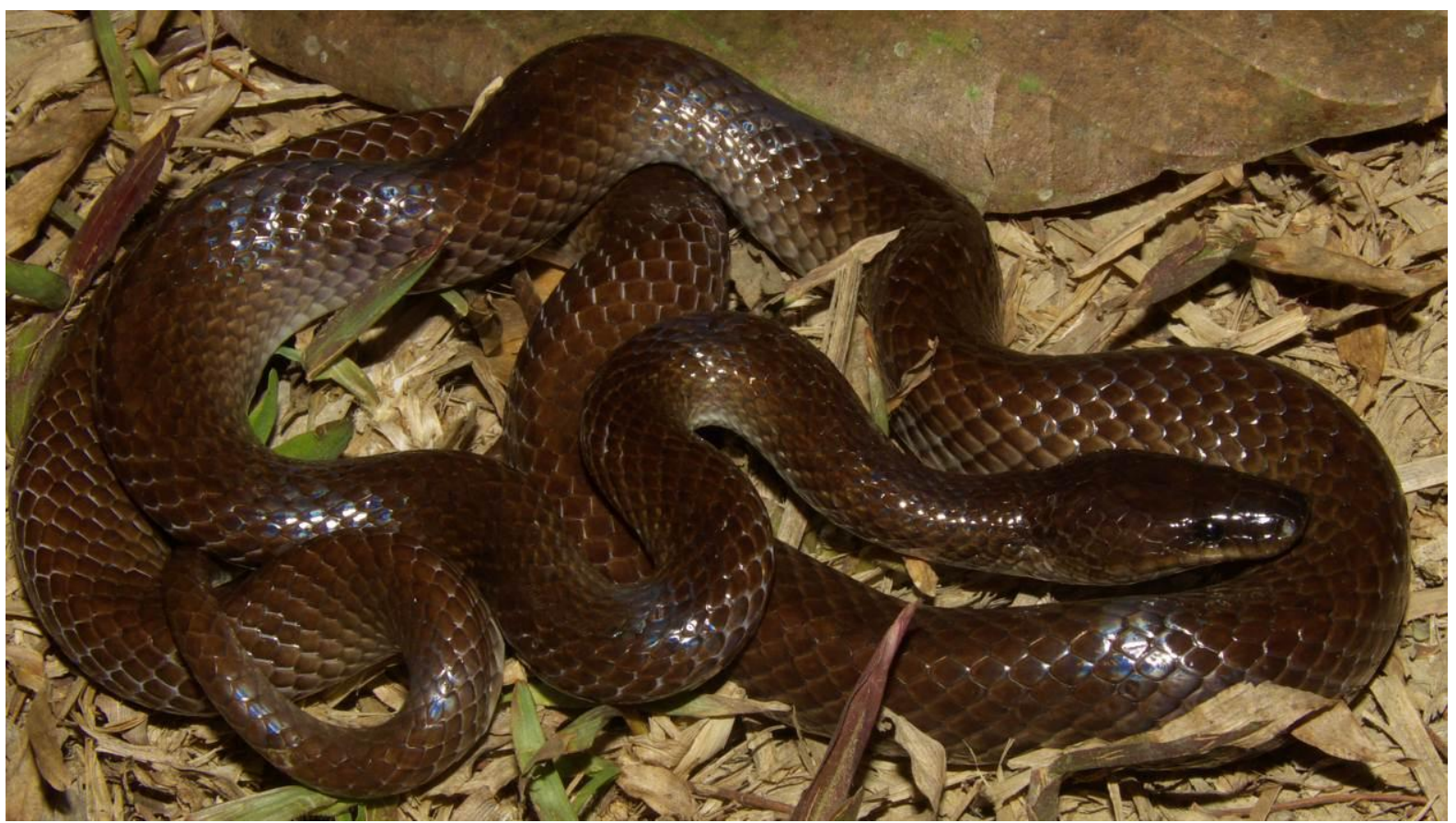

Figure 6: Adult Lycodon hypsirhinoides (Theobald, 1868) from Wandoor, South Andaman Island. 
From L. capucinus it differs in colouration (dark-brown against middle brown or purplishbrown) pattern (uniform against reticulate), the faint/absent light collar and a larger body size in males. The upper labials of $L$. capucinus usually have dark centres (Fig. 5, 7); these are missing in L. hypsirhinoides. The colouration and pattern of juveniles is also different. The males are larger than the females in $L$. hypsirhinoides, in L. capucinus the size of the sexes is more or less the same (How et al. 1996). There is no or nearly no ontogenetic shift in colour in L. capucinus, while it is distinct in L. hypsirhinoides (see also Smith 1943 and Fig. 3, 7).

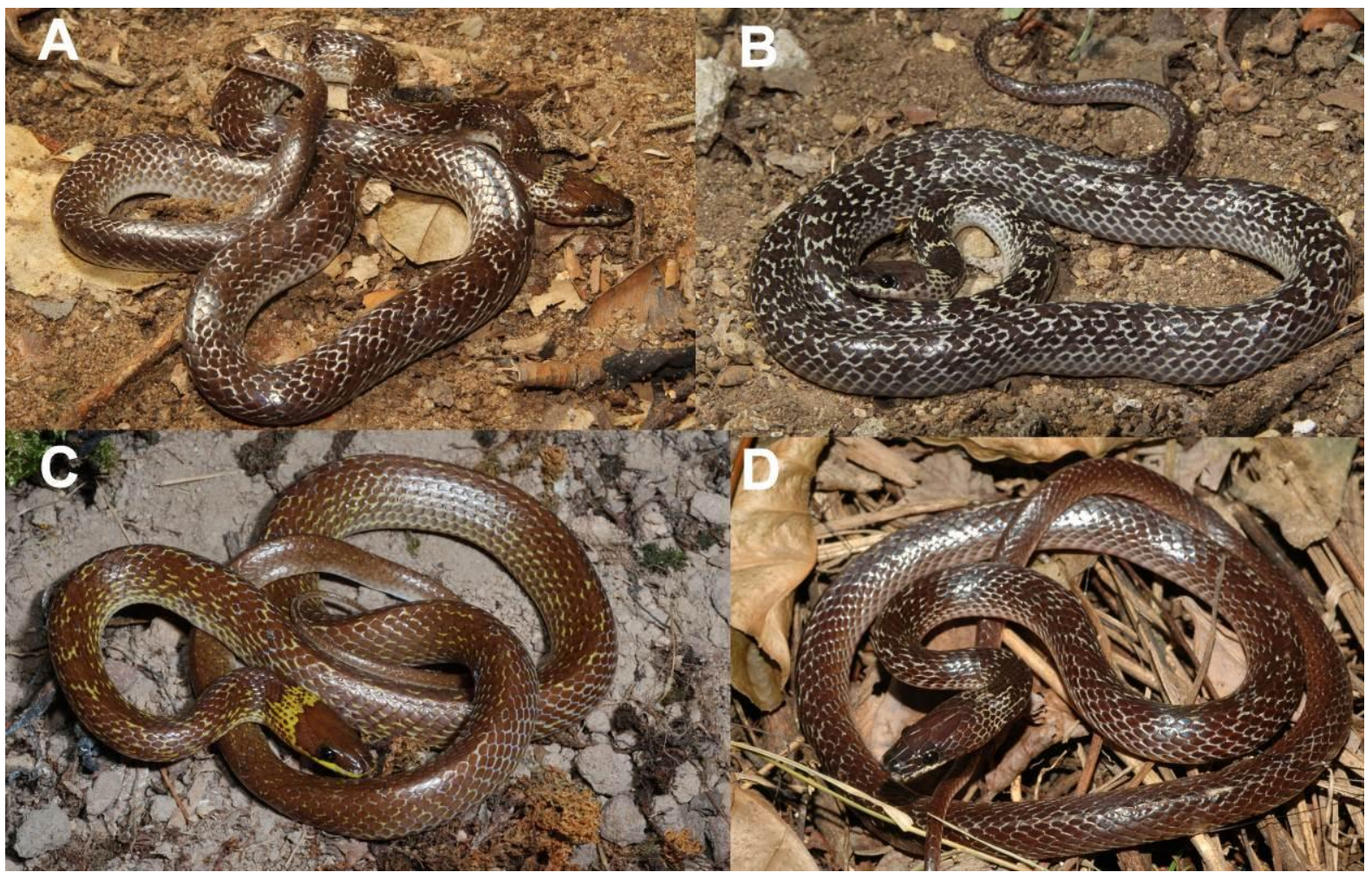

Figure 7: Lycodon capucinus from Southeast Asia: A, Pulau Perhentian Kecil, East coast of West-Malaysia (Photo: Tom Charlton); B, Komodo, Indonesia (Photo: Tom Charlton); C, Mainland West Malaysia; D, Mindoro, Philippines
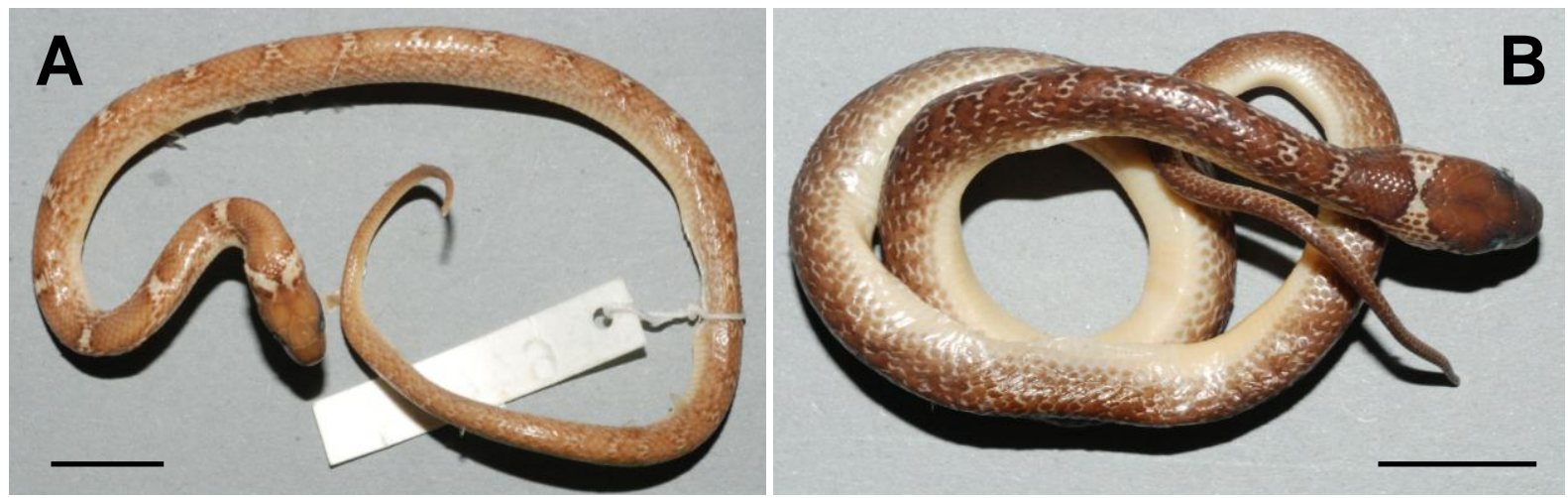

Figure 8: A, Juvenile L. capucinus (SMF 55285, Pulau Menjangan Kecil, Indonesia); B, juvenile L. aulicus (SMF 64484, Lahore, Pakistan). Scale, $1 \mathrm{~cm}$. 
From L. flavicollis it differs in the smaller number of ventrals (191- 210 against 213224), a larger snout-vent length (598 against 440 , both males) and a different colouration and pattern, especially in the missing yellow band in the neck in full grown adults.

From L. tiwarii Biswas \& Sanyal, 1965, it differs in a relatively smaller tail with the relative tail length of 0.192 against 0.164 , a smaller number of ventrals (191- 210 against 218-237) and a smaller maximum number of subcaudals with 75 against 102 . The juveniles of $L$. tiwarii have a light dorsal head colouration against a dark head in $L$. hypsirhinoides.

The populations of $L$. capucinus bear a striking resemblance to each other (Fig. 8). This suggests a recent colonisation of at least part of the distribution area, most probably by anthropogenic effects. Nevertheless without doubt a part of the investigated populations stem from the original distribution area.

There are two other species of Lycodon reported from Andaman and Nicobar Islands. These are Lycodon tiwarii Biswas \& Sanyal, 1965 and Lycodon subcinctus Boie, 1827 (Biswas \& Sanyal, 1965; Das, 1999; Vijayakumar \& David, 2005; Harikrishnan et al., 2010). The holotype of Lycodon tiwarii is from Mayabunder in Middle Andaman, a locality within the range of Lycodon hypsirhinoides. All subsequent records of $L$. tiwarii including the paratype are from Nicobar Islands. L. subcinctus is also known only from Great Nicobar Island and not in the Andaman Islands. If one considers the possibility of erroneous type locality for $L$. tiwarii, the three species of wolfsnakes in the Andaman Islands will have mutually exclusive distribution ranges ie. L. hypsirhinoides in the Andaman Islands, $L$. tiwarii in the Car Nicobar and Nancowry group of islands and $L$. subcinctus in the Great Nicobar Island (Fig. 9).

In 1827 F. Boie described Lycodon unicolor based on the manuscript of $\mathrm{H}$. Boie and Russell's plate 39 (1810). The manuscript of H. Boie was never published. The accompanying text of Russell gives for the specimen on plate
39 the following data: 265 ventrals +67 subcaudals, length 4 feet 10 inches. Of the subcaudals apparently 36 are divided, 28 entire and the last 3 divided again. The locality is Bengal and the specimen was received from Alexander Russell of Calcutta in June 1788. The identity of this specimen cannot be resolved at this moment, but due to the high ventral count, it cannot belong to one of the three species treated.

It is important to note the distinctness of the population from the Andamans. It cannot be ruled out, that in near future L. capucinus might reach the Andamans and even displace the population of L. hypsirhinoides. Perhaps it is already there, but unnoticed due to limited collection or taxonomic confusions. It is the main concern of this paper to work against this.

\section{Acknowledgements}

We thank four anonymous reviewers for their critical and constructive comments, which contributed to the honing of the final text. We thank G. Norval and S.R. Chandramouli for proofreading an earlier version of the manuscript. Thanks to S. Ghodke for his expertise. We also thank P. Campbell (BMNH), Jens Vindum, Alan Leviton (CAS), $\mathrm{H}$. Grillitsch, F. Tiedemann, S. Schweiger and R. Gemel (NMW), G. Köhler and L. Acker (SMF), D. Rödder and W. Böhme (ZFMK), M.-O. Roedel, F. Tillack (ZMB) \& B. H. C. Murthy (ZSI) for letting us examine preserved specimens. HS thanks K. Vasudevan (Wildlife Institute of India), Department of Science \& Technology, Government of India, and Andaman \& Nicobar Environmental Team (ANET) for the support provided in work in the Andaman Islands. T. Charlton was so kind to support us with his fine pictures. V. Deepak and A. Das are thanked for the images of the holotype of Tytleria hypsirhinoides. V. Wallach was so kind to send us information on plate 37 of the book of Russell. A special thank you goes to our friend S. R. Chandramouli for all the time he spent with us in the field. Finally we would like to thank Van Wallach (Harvard University - USA) and Colin Chapman (McGill University - Canada) for editing and reviewing the manuscript. 


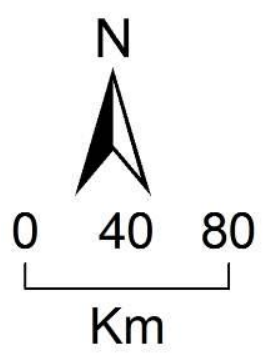

\section{Andaman Islands}
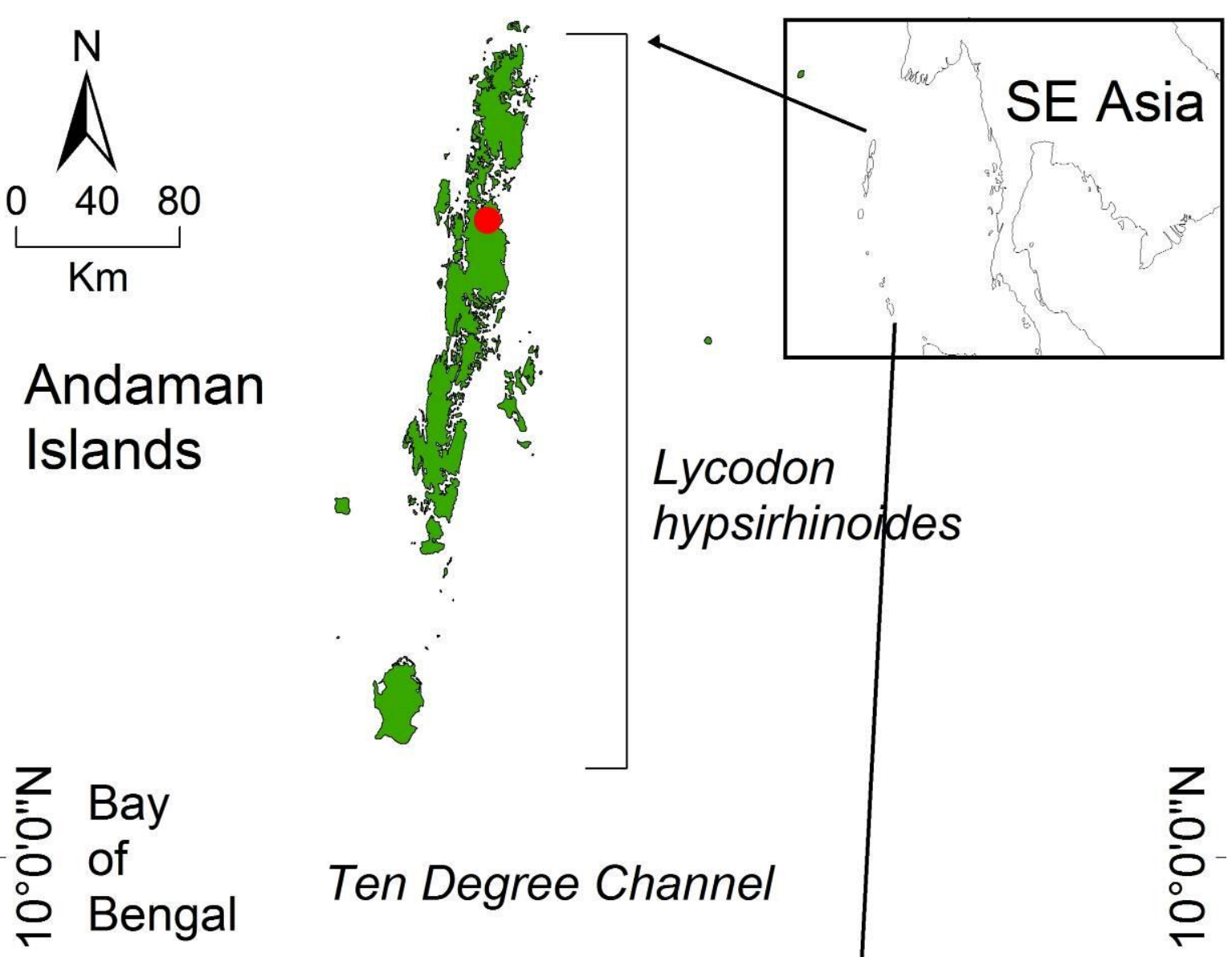

\section{Ten Degree Channel}

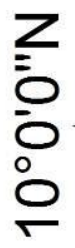

\section{Lycodon tiwarii}

\section{Nicobar Islands}

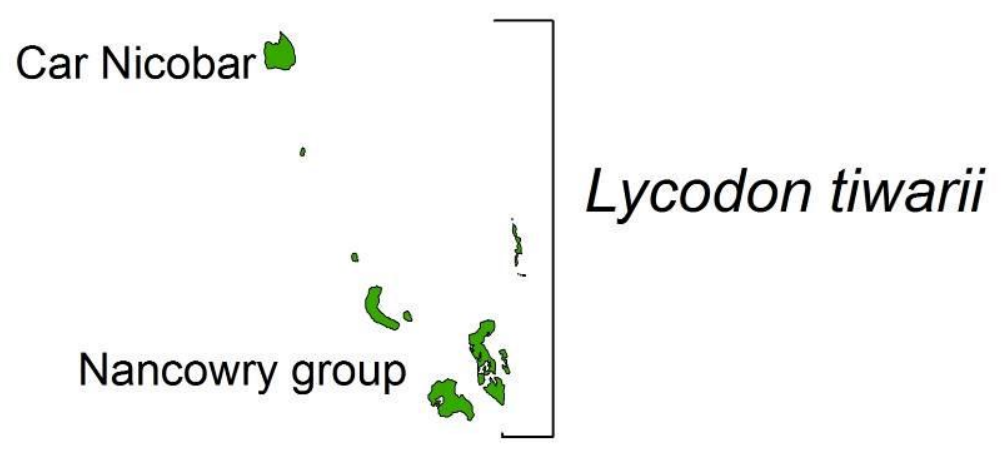

\section{Great Nicobar}

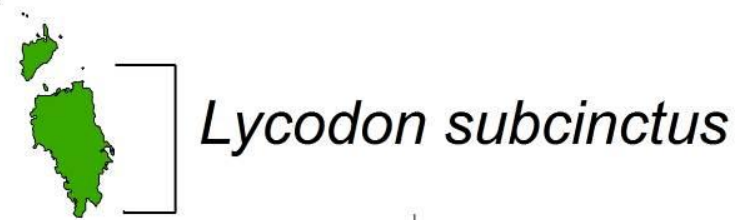

Figure 9: The distribution of three Lycodon species known from Andaman and Nicobar Islands. The type locality of Lycodon hypsirhinoides is "Andamans, in the Bay of Bengal". The holotype of L. tiwarii is from Mayabunder (indicated by a red dot), North Andaman, Andaman Islands, while the paratype is from Car Nicobar Island in the Nicobar Islands. 


\section{Literature cited}

Adler, K. and E. Zhao. 1995. The proper generic name for the Asian wolf snakes: Lycodon (Serpentes: Colubridae). Sichuan Journal of Zoology, 14: 74-75.

Biswas, S. and Sanyal, D. P. 1965. A new species of wolf snake of the genus Lycodon Boie (Reptilia: Serpentes: Colubridae) from the Andaman and Nicobar Islands. Proceedings of the Zoological Society of Calcutta, 18: 137-141.

Boie, F., 1827. Bemerkungen über Merrem's Versuch eines Systems der Amphibien. Marburg. 1820. Erste Lieferung: Ophidier. Isis von Oken 20 (10): 508-566.

Boulenger, G. A., 1893. Catalogue of the snakes in the British Museum (Natural History), Vol. I., containing the families Typhlopidae, Glauconiidae, Boidae, Ilysiidae, Uropeltidae, Xenopeltidae, and Colubridae Aglyphae, part. British Museum of Natural History, London: xiii+448, Pl. 1-28.

Cogger, H., 2006. National recovery plan for Lister's gecko Lepidodactylus listeri and the Christmas Island blind snake Typhlops exocoeti. Department of the Environment and Heritage, Canberra: 10.

Das, I., 1999. Biogeography of the amphibians and reptiles of Andaman and Nicobar Islands, India. In: H. Ota (ed.). Tropical Island Herpetofauna: Origin, Current Diversity and Conservation. Elsevier Science Ltd, Amsterdam: 43-77.

Das, I., B. Dattagupta and N. C. Gayen, 1998. History and catalogue of reptile types in the collection of the Zoological Survey of India. Journal of South Asian Natural History, 3: 121172.

David, P. and G. Vogel. 1996. The Snakes of Sumatra. An annotated checklist and key with natural history notes. Edition Chimaira, Frankfurt am Main: 260.

de Lang, R. and G. Vogel. 2005. The snakes of Sulawesi. A field guide to the land snakes of Sulawesi with identification keys. Edition Chimaira, Frankfurt am Main: 312.

Dowling, H. G. 1951. A proposed standard system of counting ventral in snakes. Journal of Herpetology, 1 (5): 97-99.
Fritts, T. H., 1993. The common wolf snake, Lycodon aulicus capucinus, a recent colonists of Christmas Island in the Indian Oceana. Wildlife Research, 20: 261-265.

Harikrishnan, S., B. C. Choudhary and K. Vasudevan, 2010. Recent records of snakes (Squamata: Serpentes) from Nicobar Islands, India. Journal of Threatened Taxa, 2 (11): 12971300 .

How, R. A., L. H. Schmitt and A. Suyanto, 1996. Geographical variation in the morphology of four snake species from the Lesser Sunda Islands, eastern Indonesia. Biological Journal of the Linnean Society, 59: 439-456.

Lanza, B., 1999. A new species of Lycodon from the Philippines, with a key to the genus (Reptilia, Serpentes, Colubridae). Tropical Zoology, 12 (1): 89-104.

Leviton, A. E., 1965. Contribution to a review of Philippine snakes VIII. The snakes of the genus Lycodon. The Philippine Journal of Science, 94: 117-140.

Malkmus, R., U. Manthey, G. Vogel, P. Hoffmann and J. Kosuch, 2002. Amphibians and reptiles of Mount Kinabalu (North Borneo). A. R. G. Gantner Verlag Kommanditgesellschaft, Ruggell: 424.

Mertens R., 1930. Die Amphibien und Reptilien der Insel Bali, Lombok, Sumbawa und Flores. Abhandlungen der Senckenbergischen Naturforschenden Gesellschaft, 42: 117-344.

Mukherjee D. and S. Bhupathy, 2007. A new species of Wolf Snake (Serpentes: Colubridae: Lycodon) from Anaikatti Hills, Western Ghats, Tamil Nadu, India. Russian Journal of Herpetology, 14: 21-26.

Ota H. and C. A. Ross, 1994. Four new species of Lycodon (Serpentes: Colubridae) from the Northern Philippines. Copeia, 1994: 159-174.

Rodda, G. H. and T. H. Fritts, 1992. The impact of the introduction of the colubrid snake Boiga irregularis on Guam's lizards. Journal of Herpetology, 26: 166-174.

Rodda, G. H., Y. Sawai, D. Chiszar and H. Tanaka (eds.), 1999. Problem snake management: The habu and the brown treesnake. Cornell University Press, Ithaca, New York: 534. 
Russell, P., 1801-1809 [1810?]. A continuation of an account of Indian Serpents; containing descriptions and figures from specimens and drawings, transmitted from various parts of India. Presented to the Hon. The Court of the East India Company, and published by their order, under the Superintendence of the author. G. and W. Nicol, London. $\mathrm{i}-\mathrm{xv}+53+(1-4)$ portrait, pl. 1-45.

Smith, L. A., 1988. Lycodon aulicus capucinus a colubrid snake introduced to Christmas Island, Indian Ocean. Records of the Western Australian Museum 14: 251-252.

Smith, M. A., 1943. The Fauna of British India, Ceylon and Burma, including the whole of the Indo-chinese subregion. Reptilia and Amphibia. Vol. III, Serpentes, Taylor and Francis, London: $\mathrm{xii}+583$.

Taylor, E. H., 1965. The serpents of Thailand and adjacent waters. University of Kansas Science Bulletin, 45 (9): 609-1096.

Theobald, W., 1868. Catalogue of Reptiles in the Museum of Asiatic Society of Bengal: 66.

Uetz, P., 2012. The Reptile Database. Retrieved from: http://www.reptile-database.org 12/9/2012.
Vijayakumar, S. P. and P. David, 2006. Taxonomy, natural history and distribution of the snakes of Nicobar Islands (India), based on new materials and with an emphasis on endemic species. Russian Journal of Herpetology, 13 (1): 11-40.

Vogel, G. and P. David, 2010. A new species of the genus Lycodon (Boie, 1826) from Yunnan Province, China (Serpentes: Colubridae). Bonn zoological Bulletin, 57 (2): 289-296.

Vogel, G. and J. Luo, 2011. A new species of the genus Lycodon (Boie, 1826) from the southwestern China (Squamata: Colubridae). Zootaxa, 2807: 29-40.

Vogel, G., P. David, O.S.G. Pauwels, M. Sumontha, G. Norval, R. Hendrix, N.T. Vu and T. Ziegler, 2009. A revision of Lycodon ruhstrati (Fischer 1886) auctorum (Squamata Colubridae), with the description of a new species from Thailand and a new subspecies from the Asian mainland. Tropical Zoology, 22: 131-182.

Zhang, J., K. Jiang, G. Vogel and D. Q. Rao, 2011. A new species of the genus Lycodon (Squamata, Colubridae) from Sichuan Province, China. Zootaxa, 2982: 59-68.

\section{Appendix I. Examined materials}

Lycodon hypsirhinodes: ZSIC 8145 (holotype), Andamans, (In the Bay of Bengal, India) ; BM 1987.889 Sippighat, South Andaman; BM 1940.3.7.11 Andamans; BM 1940.3.7.12 Andamans; HC 040 Wandoor, South Andaman Island; HC 137 Tarmugli Island, HC 177 Krishnanallah, Little Andaman Island, HC 216 Neil Island, HC 218 Wandoor, South Andaman Island; NMW 21686:1\&2 Andamans; NMW 14479 Andamans.

Lycodon capucinus: BM 97.12.30.35, Atapupu, West Timor; BM 1969.824, Bangkok; BM 1977.845 Semarang, Java; BM 1977.846, Semarang, Java; SMF 55285 Pulau Menjangan Kecil, Kepulauan Karimujawa, Indonesia; ZFMK 88296, Son Tra, Vietnam; ZFMK 86832 Son Tra, Vietnam; ZFMK 32255, Java; ZFMK 32256, Java; ZFMK 84097, Flores, Indonesia; ZFMK 32254, Borneo; ZFMK 49252, Lombok; ZFMK 63607, Samar, Philippines; ZFMK 70447, Samar, Philippines; ZMB 65689, Java.

Lycodon aulicus: BM 82.8.26.22, Kinelly Hills, India; BM 1984.1216, Royal Chitwan, Nepal; BM 1921.6.15.3, Bangalore, India; CAS-SU 12263, Bisrampur, Jharkhand State, India; CAS 20500, Pleasant Beach Resort, Rakhine State, Myanmar; CAS 215387, Yin Ma Bin Township, Yinpaungtaing Village, Sagaing division, Myanmar; CAS 219800, Bogalay Township, Meinmahla Kyun Wildlife Sanctuary, Mi Gyaung Gaung Pok Camp,Pyapone District, Ayeyarwady Division, Myanmar; CAS 245960, Yebyu Township, Tanintharyi Nature Reserve, vicinity of Khotama military camp, along Khotama stream, Dewei District, Tanintharyi Division, Myanmar; NMW 21697:2, Madras, India; NMW 37406:2, Ahmednagar, Maharashtra, India; SMF 32463, Agra, India; SMF 64484, Lahore, Pakistan; ZFMK 29976, Mauritius; ZFMK 21766, Mascarenes, Reunion, Manapany; ZFMK 29977, Mauritius; ZMB 1791, "Bengal”.

Lycodon cf. striatus: ZFMK 52511, Kitulgala, Sri Lanka; ZFMK 52137, Kitulgala, Sri Lanka; ZFMK 52510, Sri Lanka. 
Lycodon cf. osmanhilli: ZFMK 32253, Sri Lanka.

Lycodon tiwarii: ZSI 20849 (holotype), Mayabunder, North Andaman Island; ZSI 20851, donated by Govt. Hospital, Car Nicobar.

Lycodon subcinctus: ZSI (Port Blair) 10643, Govind Nagar, Great Nicobar Island

\section{Appendix II. Characters used (for abbreviations, see material and methods)}

Morphometry: Snout-vent length $(\mathrm{mm})$; Tail length $(\mathrm{mm})$; Total length $(\mathrm{mm})$; Relative tail length $\mathrm{TaL} / \mathrm{TL}$; Head length (mm); Head width at the widest part; Eye diameter (mm).

Scalation: Dorsal scale rows at neck (at 1 head length behind head)/ at midbody/ before vent; Ventral plates; Number of preventrals; Subcaudal plates; Cloacal (anal) plate: (1) single and (2) divided; Number of loreal scales at left/right; Number of supralabials at left/right; Numbers of the supralabials entering orbit at left/right; Number of infralabials at left/right; Total number of infralabials; Number of infralabials in contact with anterior chin shield; Number of preoculars at left/right; Number of postoculars at left/right; Number of anterior temporals at left/right; Number of posterior temporals at left/right; Total number of preoculars.

Pattern: Body colour; Existence of reticulations; Existence of a band in the neck region; Existence of bands on body; Upper labials with light margins or not; Upper labials totally white or not. 